\title{
EVALUATION OF THE LUMBAR SAFETY TRIANGLE THROUGH MAGNETIC RESONANCE IMAGING
}

\author{
AVALIAÇÃO DO TRIÂNGULO DE SEGURANÇA LOMBAR POR MEIO DA RESSONÂNCIA \\ MAGNETICA
}

\section{EVALUACIÓN DEL TRIÁNGULO DE SEGURIDAD LUMBAR POR MEDIO DE LA RESONANCIA MAGNÉTICA}

Fernando Augusto Dannebrock, ${ }^{1}$ Erasmo de Abreu Zardo, ${ }^{1}$ Marcus Sofia Ziegler, ${ }^{1}$ Carlos Marcelo Donazar Severo, ${ }^{1}$ Joel Abramczuk, ${ }^{1}$ Emiliano Vialle, ${ }^{2}$ Graciane Radaelli, ${ }^{3}$ Carla Helena Augustin Schwanke, ${ }^{4}$ Ricardo Bernardi Soder ${ }^{3}$

\author{
1. Pontifícia Universidade Católica do Rio Grande do Sul, Instituto Gaúcho de Cirurgia da Coluna Vertebral, Hospital São Lucas, Porto Alegre, RS, Brazil. \\ 2. Pontifícia Universidade Católica do Paraná, Hospital Universitário Cajuru, Curitiba, PR, Brazil. \\ 3. Pontifícia Universidade Católica do Rio Grande do Sul, Instituto do Cérebro do Rio Grande do Sul, Porto Alegre, RS, Brazil. \\ 4. Pontifícia Universidade Católica do Rio Grande do Sul, Escola de Medicina, Instituto de Geriatria e Gerontologia, Porto Alegre, RS, Brazil.
}

\begin{abstract}
Objective: To evaluate the lumbar triangular safety zone, its boundaries and its relationship with the dorsal root ganglion through Magnetic Resonance Imaging (MRI). Methods: The boundaries, shape and dimensions of 303 triangular safety zones were analyzed in Tesla 3.0 Magnetic Resonance Imaging (MRI) coronal sections from L2 to L5, including the dorsal root ganglion. Results: The sample consisted of 101 patients with a mean age of 32 years. The height of the triangular safety zone was formed by the lateral edge of the dura mater, the width by the upper plateau of the lower vertebra and the hypotenuse by the corresponding nerve root. The mean dimensions and the area varied according to the level studied. The dorsal root ganglion invaded the dimensions of the triangle in all the images studied. Conclusion: Based on the data and the analyses performed, we concluded that knowledge of the boundaries of the triangular safety zone through MRI increases the safety of minimally invasive procedures in the lumbar spine. Level of evidence I; Diagnostic studies - Investigation of a diagnostic test.
\end{abstract}

Keywords: Spine; Anatomy; Minimally Invasive Surgical Procedures; Ganglia, Spinal; Magnetic Resonance Imaging.

\section{RESUMO}

Objetivo: Avaliar a zona triangular de segurança lombar, seus limites e sua relação com o gânglio da raiz dorsal por meio da ressonância magnética (RM). Métodos: Foram estudados os limites, o formato e as dimensões de 303 zonas triangulares de segurança no corte coronal de RM 3.0 Tesla de L2 a L5, incluindo o gânglio da raiz dorsal. Resultados: A amostra foi composta por 101 pacientes com média de idade de 32 anos. A altura da zona triangular de segurança era formada pela borda lateral da dura-máter; a largura, pelo platô superior da vértebra inferior; e a hipotenusa, pela raiz nervosa correspondente. A média das dimensões, assim como a área, variaram conforme o nível estudado. O gânglio da raiz dorsal invadiu as dimensões do triângulo em todas as imagens estudadas. Conclusão: Baseados nos dados e nas análises realizadas, concluímos que o conhecimento dos limites da zona triangular de segurança, por meio da imagem da RM, aumenta a segurança dos procedimentos minimamente invasivos na coluna lombar. Nível de evidência I; Estudos diagnósticos-Investigação de um exame para diagnóstico.

Descritores: Coluna Vertebral; Anatomia; Procedimentos Cirúrgicos Minimamente Invasivos; Gânglios Espinais; Imagem por Ressonância Magnética.

\section{RESUMEN}

Objetivo: Evaluar la zona triangular de seguridad lumbar, sus límites y su relación con el ganglio de la raíz dorsal a través de la Resonancia Magnética (RM). Métodos: Se estudiaron los límites, el formato y las dimensiones de 303 zonas triangulares de seguridad en el corte coronal de RM 3.0 Tesla de L2 a L5, incluyendo el ganglio de la raíz dorsal. Resultados: La muestra fue compuesta por 101 pacientes, con promedio de edad de 32 años. La altura de la zona triangular de seguridad estaba formada por el borde lateral de la duramadre, el ancho por la meseta superior de la vértebra inferior y la hipotenusa por la raíz nerviosa correspondiente. El promedio de las dimensiones, así como el área, variaron según el nivel estudiado. El ganglio de la raíz dorsal invadió las dimensiones del triángulo en todas las imágenes estudiadas. Conclusión: Basándose en los datos y análisis realizados, concluimos que el conocimiento de los límites de la zona triangular de seguridad a través de la imagen de RM aumenta la seguridad de los procedimientos mínimamente invasivos en la columna lumbar. Nivel de evidencia I; Estudios diagnósticos - Investigación de un examen para diagnóstico.

Descriptores: Columna Vertebral; Anatomía; Procedimientos Quirúrgicos Mínimamente Invasivos; Ganglios Espinales; Imagen por Resonancia Magnética.

The study was conducted at the Instituto do Cérebro do Rio Grande do Sul da Pontifícia Universidade Católica do Rio Grande do Sul (InsCer-PUCRS), Porto Alegre, RS, Brazil. Correspondence: Fernando Augusto Dannebrock. Rua Gabriel Miró, 256, Canoas, RS, Brasil. 92.025-660. fdannebrock@gmail.com 


\section{INTRODUCTION}

Constant advancements in minimally invasive techniques and therapeutic options for spinal diseases create a growing need for the study of various concepts related to surgical approaches. These approaches have the advantage of minimal tissue damage and shorter surgical times, shorter hospital stays, preservation of the musculature, lower infection rates, in addition to a faster return to activities. However, they require thorough knowledge of the neural structures and their relationships with the other spinal components, allowing the safe execution of these procedures. ${ }^{1,2}$

In 1983, Kambin and Gellmann ${ }^{3}$ described a triangular safety zone for the transforaminal approach called "Kambin's triangle". Defined as a three-dimensional anatomical triangle located over the dorsolateral intervertebral disc of the lumbar spine, this concept is used not only in minimally invasive procedures, but also for lumbar fusion techniques. Mirkovic, Schwartz and Glazier ${ }^{4}$ reinforce these concepts and describe the dura mater as the medial boundary of the triangle, the upper vertebral plateau as the lower boundary and the hypotenuse as the corresponding spinal nerve. The relationship of the dorsal root ganglion to the triangle of safety is not described in any of these studies.

The size of the dorsal root ganglia varies with the vertebral level. Most of the ganglia are directly below the vertebral pedicles with one third overlapping a part of the lateral intervertebral disc. These relationships may assist an understanding of the neurocompressive and lumbosacral disorders and should be observed during the insertion of surgical material. 5,6

In view of the scarcity of literature about the description of the safety triangle in 3.0 Tesla Magnetic Resonance Imaging (MRI), the authors conducted a descriptive study of the safety triangle image in the lumbar spine, aiming to define its boundaries and its corresponding measurements, in addition to its area at different lumbar levels.

MRI was chosen as the imaging method to be used because of its several advantages over the other imaging methods, such as not using ionizing radiation, its much wider range of available contrast for soft tissue, and its more detailed representation of the anatomy. ${ }^{7}$

This study also aims to describe the location of the dorsal root ganglion in relation to the triangle of safety, aiding minimally invasive procedures in the lumbar spine.

\section{METHODS}

This is an observational retrospective cohort study. The 3.0 Tesla MRI images of 101 patients without evidence of any lumbar spine abnormalities in the imaging examination were included in the study. All the examinations were performed at the Instituto do Cérebro da Pontifícia Universidade Católica do Rio Grande do Sul (InsCer-PUCRS) during the period from November 2016 to September 2017.

The research Project was approved by the Institutional Review Board of the Pontifícia Universidade Católica do Rio Grande do Sul (CEP/PUCRS) as opinion no. 2.538.975 and CAAE no. 84253418.9.0000.5336. Since only MRIs of patients who had already undergone this examination were to be reviewed, no informed consent forms were obtained. However, all researchers involved in the study signed a confidentiality agreement for the use of the data.

The patients underwent examination on a GE 3.0 Tesla Signa HDXT spine coil device. With the patient in the supine position, the sequence was performed in the oblique/coronal plane with its respective parameters: Coronal T2 FSE-XL, using parameters of FOV $=32 \mathrm{~cm}$, slice thickness $=2 \mathrm{~mm}$, with spacing of $10 \%=0.2 \mathrm{~mm}$, matrix $=448$ $X 320$, number of slices $=22, \mathrm{TE}=80$ and $\mathrm{TR}=3700$ us.

Three-hundred and three (303) triangular safety zones from the second lumbar vertebra (L2) to the fifth lumbar vertebra (L5) were studied. Measurements of the triangular safety zones were taken in the coronal slices (Figure 1), using the digital ruler available in the InsCer image interpretation software. The following measurements were taken of L2-L5: height, base and hypotenuse of the safety triangle (Figure 2). Segment L5-S1 was not studied because of a technical limitation in the images obtained.

All the MRIs were evaluated by two researchers at two different

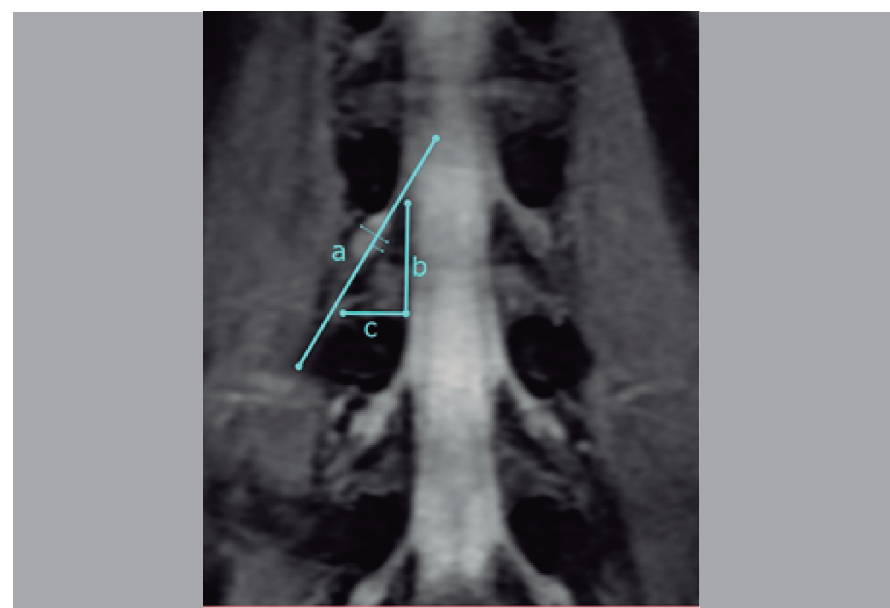

Figure 1. Anatomical aspect of the coronal slice of the lumbar spine with its respective safety triangle boundaries and its relationship with the dorsal root ganglion.

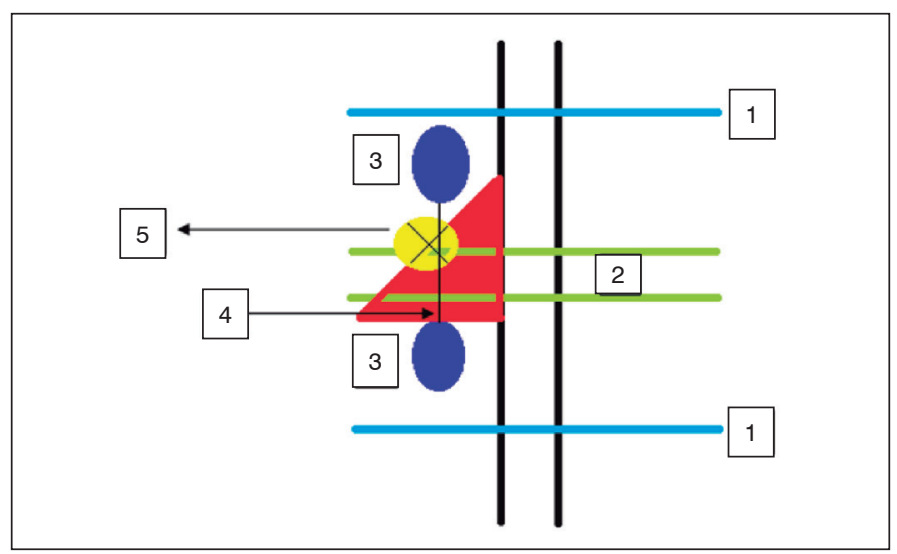

Figure 2. Schematic aspect of the safety triangle (ST) with the respective measurements taken in the study.

times, with an interval of time of approximately one month between the two evaluations.

Key:

1. Limits of the vertebral bodies

2. Disc space

3. Pedicles

4. Interpedicular distance

5. Dorsal root ganglion with its respective diameters

6. Triangular area in red: triangular safety zone $(A, B, H)$

A. Height of the ST: lateral edge of the dura mater with perpendicular extension of the vertebral plateau of the lower vertebra to the axilla of the emergent upper nerve root

B. Base of the ST: upper vertebral plateau of the lower vertebra extending medially from the dura mater to the medial edge of the emergent spinal nerve, laterally

$H$. Hypotenuse of the ST: length of the spinal nerve, extending from the axilla of the emergent nerve root of the upper vertebral plateau of the lower vertebra

The data were stored in an Excel spreadsheet and analyzed with the SPSS 21.0 statistical package. The normality of distribution of the quantitative variables was verified by means of the Kolmogorov-Smirnov test. The variables were described as mean, standard deviation, standard error and minimum and maximum values.

The research project was reviewed and approved by the Institutional Review Board of the Pontifícia Universidade Católica do Rio Grande do Sul (CEP/PUCRS) as opinion no. 2.538.975 and CAAE no. 84253418.9.0000.5336. 


\section{RESULTS}

The age of the sample ranged from 20 to 40 years and most patients were male.

The results obtained in the evaluation of the 303 triangular safety zones are described in Tables 1 to 7 , presented in sequence. These highlight the number of measurements $(\mathrm{N})$, the mean, minimum and maximum values in millimeters, the standard deviation (SD) and the standard error (SE).

Table 1. Measurement of the base of the safety triangle.

\begin{tabular}{c|c|c|c|c|c|c}
\hline Level & $\mathbf{N}$ & Mean & Minimum & Maximum & SD & SE \\
\hline L2-L3 & 101 & 12.79 & 9.80 & 16.00 & 2.23 & 0.22 \\
\hline L3-L4 & 101 & 14.59 & 9.60 & 10.80 & 2.59 & 0.26 \\
\hline L4-L5 & 101 & 12.89 & 8.20 & 18.60 & 2.93 & 0.29 \\
\hline
\end{tabular}

Table 2. Measurement of the height of the safety triangle.

\begin{tabular}{c|c|c|c|c|c|c}
\hline Level & $\mathbf{N}$ & Mean & Minimum & Maximum & SD & SE \\
\hline L2-L3 & 101 & 22.37 & 18.50 & 26.10 & 2.06 & 0.21 \\
\hline L3-L4 & 101 & 23.55 & 16.60 & 28.0 & 3.61 & 0.36 \\
\hline L4-L5 & 101 & 24.82 & 20.20 & 26.30 & 1.34 & 0.13 \\
\hline
\end{tabular}

Table 3. Measurement of the hypotenuse of the safety triangle.

\begin{tabular}{c|c|c|c|c|c|c}
\hline Level & $\mathbf{N}$ & Mean & Minimum & Maximum & SD & SE \\
\hline L2-L3 & 101 & 23.77 & 21.60 & 26.40 & 1.49 & 0.15 \\
\hline L3-L4 & 101 & 28.38 & 19.50 & 34.50 & 4.33 & 0.43 \\
\hline L4-L5 & 101 & 28.71 & 23.00 & 32.90 & 2.83 & 0.28 \\
\hline
\end{tabular}

Table 4. Measurement of the largest ganglion diameter of the safety triangle.

\begin{tabular}{c|c|c|c|c|c|c}
\hline Level & $\mathbf{N}$ & Mean & Minimum & Maximum & SD & SE \\
\hline L2-L3 & 101 & 10.98 & 9.00 & 12.70 & 1.34 & 0.13 \\
\hline L3-L4 & 101 & 12.72 & 10.80 & 15.70 & 0.97 & 0.10 \\
\hline L4-L5 & 101 & 12.81 & 10.90 & 16.30 & 1.30 & 0.13 \\
\hline
\end{tabular}

Table 5. Measurement of the smallest ganglion diameter of the safety triangle.

\begin{tabular}{c|c|c|c|c|c|c}
\hline Level & $\mathbf{N}$ & Mean & Minimum & Maximum & SD & SE \\
\hline L2-L3 & 101 & 8.30 & 7.40 & 9.20 & 0.61 & 0.06 \\
\hline L3-L4 & 101 & 7.30 & 6.30 & 8.0 & 0.61 & 0.06 \\
\hline L4-L5 & 101 & 7.82 & 7.00 & 8.40 & 0.38 & 0.04 \\
\hline
\end{tabular}

Table 6. Area of the safety triangle.

\begin{tabular}{c|c|c|c|c|c|c}
\hline Level & $\mathbf{N}$ & Mean & Minimum & Maximum & SD & SE \\
\hline L2-L3 & 101 & 142.58 & 98.98 & 197.60 & 25.57 & 2.54 \\
\hline L3-L4 & 101 & 173.06 & 79.68 & 233.80 & 43.90 & 4.37 \\
\hline L4-L5 & 101 & 160.34 & 82.82 & 244.59 & 38.42 & 3.82 \\
\hline
\end{tabular}

Table 7. Measurement of the interpedicular distance of the safety triangle.

\begin{tabular}{c|c|c|c|c|c|c}
\hline Level & $\mathbf{N}$ & Mean & Minimum & Maximum & SD & SE \\
\hline L2-L3 & 101 & 23.17 & 19.40 & 26.90 & 2.16 & 0.22 \\
\hline L3-L4 & 101 & 23.34 & 19.40 & 27.00 & 2.19 & 0.22 \\
\hline L4-L5 & 101 & 23.40 & 19.40 & 26.90 & 2.18 & 0.22 \\
\hline
\end{tabular}

\section{DISCUSSION}

The most feared complication from minimally invasive spinal procedures has always been nerve root damage, especially of the dorsal root ganglion. ${ }^{8,9}$ In addition, root arterial damage can also occur causing hematoma or medullary ischemia.

The incidence of nerve root injury has been reported ranging from $1.0 \%$ to $8.9 \% .{ }^{10-12}$ Sairyo et al. ${ }^{13}$ in a case series, described $2 \%$ nerve irritation and $1 \%$ epidural hematoma. These complications can result from technical difficulties on the approach, the use of inappropriate material or even from anatomical variation of the safety triangle. According to the authors, nerve injury could occur at the insertion of the needle and/or cannula or from irritation of the dorsal root ganglion due to compression from the cannula. ${ }^{13}$ The literature also emphasizes that the needle guide must touch the caudal pedicle before entering the triangular safety zone. ${ }^{14}$

Ozer et al., ${ }^{15}$ in an anatomical study, described and classified their findings in three different types of triangles, varying according to the angles obtained between their measurements. The first type is a closed triangle without any space available between its elements, the second type is a narrow triangle and the third type is a normal triangle, as described by Kambin. ${ }^{3}$ They also state that approximately $82 \%$ of patients had a narrow space or no space in the triangle. The authors made no mention of the position of the root ganglion in relation to the triangle. ${ }^{15}$

In our study, conducted through image analysis, we observed that most patients presented triangles of type III, unlike the data described by Ozer et al. ${ }^{15}$ On the other hand, we found that the dorsal root ganglion invaded the safety triangle in all the images analyzed.

Although the type III triangle is described as normal and safe, the position of the root ganglion in relation to it must be taken into account. Thus, preoperative analysis of the safety triangle in the MRI becomes important and coupled to decision making. ${ }^{15}$

Regarding the boundaries of the triangular safety zone obtained in the images, we found that they are in accordance with those reported in the literature. ${ }^{4}$ We observed that the dimensions obtained for the sides of the triangle increased progressively, with the exception of the measurement of the base.

Regarding the height of the triangle, in L2-L3 a mean of 10.9 $\mathrm{mm}$ was obtained compared to 22.37 in our study. In L3-L4, a mean of $11.7 \mathrm{~mm}$ is reported versus 23.55. In L4-L5, a mean of 12.4 is reported as compared to 24.82 in our findings. ${ }^{4}$

In terms of the measurement of the base, in L2-L3 a mean of $16.9 \mathrm{~mm}$ was obtained versus 12.79 in our study. In L3-L4, a mean of $17.4 \mathrm{~mm}$ is cited compared to 14.59 . In L4-L5, a mean of $19.9 \mathrm{~mm}$ is reported versus 12.89 in our study. ${ }^{4}$

When we took the measurements of the hypotenuse as a parameter, we observed that in L2-L3 a mean of 20.7 was obtained as compared 23.77 in our study. In L3-L4, a mean of $21.2 \mathrm{~mm}$ was observed versus 28.38. In L4-L5, a mean of $23.6 \mathrm{~mm}$ was reported compared to 28.71 in our findings. We observed that despite the difference, the measurements of the hypotenuse are the closest to the literature. ${ }^{4}$

Although the anatomical characteristics described based on our triangles were not in accordance with the study by Mirkovik, Schwartz and Glazier, ${ }^{4}$ our findings are in line with the data described by Choi and Basile ${ }^{16}$ in their anatomical study. Vialle et al., ${ }^{17}$ reported numbers close to ours in their anatomical study.

The measurements of the area of the triangles varied according to the level, being greater at the L3-L4 level. Hoshide, Feldman and Taylor $^{18}$ described a progressive increase of the areas measured for the triangles from $L 1-L 2$ to $L 4-L 5 .{ }^{18}$ In contrast, Hardenbrook et al. ${ }^{19}$ reported that the area of the triangles varied by level, which is in agreement with our findings. These authors concluded that the safety triangle was a relatively large and safe area for minimally invasive procedures, contrary to the data presented by Ozer et al. ${ }^{15}$

One of the possible reasons to explain this incompatibility of findings between the studies would be the shape of the proposed triangles. Mirkovic, Schwartz and Glazier ${ }^{4}$ describe their triangle with the width greater than the height. Choi and Basile ${ }^{16}$ describe the triangle with its height greater that its width. Vialle et al. ${ }^{17}$ describe the triangle with the presence of the dorsal root ganglion, proposing a rectangular safety zone (Figure 3 ).

Lertudomphonwanit et al., ${ }^{20}$ in a 2016 anatomical study of cadavers, demonstrate and suggest that the true work zone would be trapezoidal instead of the typical right angle triangle. ${ }^{20,21}$ These researchers consider the disc height to be the limit of the medial height of the trapezoid. They also describe the trapezoidal area as varying by the level studied, which is in agreement with our reports. According to their study, disc height can be increased by distraction of the disc - which would increase the height of the trapezoid. And the base of the triangle can be increased by the traction capacity 


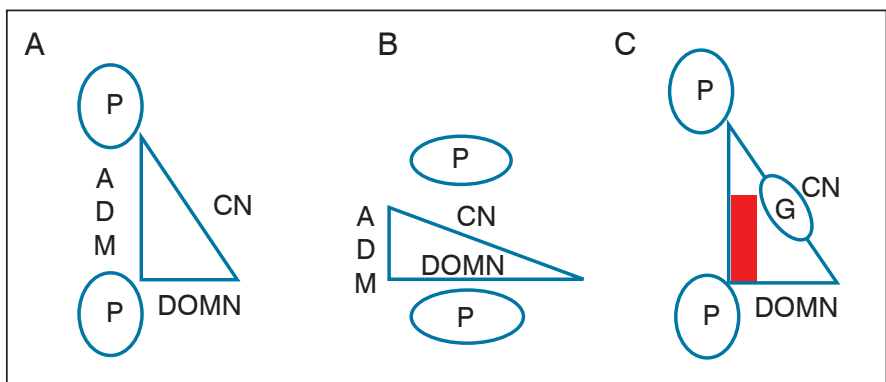

Figure 3. Comparative schematic aspect of the safety zones of the spinal nerve. Source: adapted from Vialle et al. ${ }^{17}$

of the nerve root in endoscopic procedures. However, the study makes no mention of the position of the dorsal root ganglion. It is understood from their description that the dorsal root ganglion would be inside the boundaries of the trapezoid, which would increase the chance of surgical complications. ${ }^{20}$

The use of MRI as a preoperative evaluation tool in patients undergoing minimally invasive procedures demonstrates excellent detection of nerve anatomy and its relationships, ${ }^{22}$ being able to suppress the vascular and/or fat signal to create selective images. ${ }^{23}$

There may be changes in the anatomical relationships with the use of cadavers to study the triangular safety zone, since the tension within the tissues is reduced, particularly the thecal sac and the nerve root. Studies demonstrate that for every $10 \%$ of formalin fixation, the mean linear shrinkage was $4.5 \%{ }^{24}$ In addition, manipulation and surgical dissection can lead to the displacement of some structures.

Guan et al. ${ }^{25}$ described their morphometric analysis of the lumbar safety zones in endoscopic discectomies, based on MRI scans. They also detail their analysis of the images in the coronal and sagittal planes of 32 patients. ${ }^{25}$ In their conclusions, they report results similar to ours, particularly regarding the size of the base of the safety zone. However, they do not mention studying the area of the triangle, but rather of the angle formed by the nerve root with its base. Finally, they do not describe the location of the dorsal root ganglion in relation to the safety zone. ${ }^{25}$

The strong point of our study is the inclusion of the dorsal root ganglion in all of the measurements performed. As a limitation, we note the non-measurement of the triangular zone in the sagittal section, as well as the comparison with the measurements of the coronal section. This may interfere in some way with the results presented, since it is a three-dimensional structure.

The objective of this study was to study the anatomy of the triangular safety zone in living patients and its relationship with the dorsal root ganglion.

\section{CONCLUSIONS}

$\mathrm{MRI}$ is a safe non-invasive method for evaluating the anatomical dimensions of the triangular safety zone in minimally invasive procedures, as it permits accurate assessment of its three-dimensional anatomy, enhancing the safety of the procedure.

The anatomical boundaries of the triangular safety zone found in $\mathrm{MRI}$ images are in agreement with those of the works published in the literature. The dimensions of the sides of the triangles, as well as their areas, vary in accordance with the level studied. In all the measurements taken, the dorsal root ganglion invaded the boundaries of the safety triangle. This study reinforces the hypothesis that a rectangular safety zone would have a lower rate of neurological complications.

All authors declare no potential conflict of interest related to this article.

CONTRIBUTION OF THE AUTHORS: Each author made significant individual contributions to this manuscript. FAD (0000-0002-7640-8956* ${ }^{\star}$, RBS $(0000-0002-1445-0737)^{\star}$, EAZ (0000-0002-4922-6962)*, MSZ (0000-0002-6051-0147)*, JA (0000-0002-4122-804X)*, CMDS (0000-0002-5944-7750)* and EV (0000-0003-1157-4889)* contributed to the intellectual concept of the study and conducted the biographical research. FAD, GR (0000-00021208-362X)*, RBS, JA and CMDS collected the clinical data. FAD, GR, CHAS (0000-0002-0397-771X)* and EV evaluated the statistical analysis data. FAD, EAZ and MSZ prepared the first version of the manuscript. RBS, JA, CMDS, EV and CHAS reviewed the manuscript and contributed intellectually to the preparation of the final version. *ORCID (Open Researcher and Contributor ID).

\section{REFERENCES}

1. Oppenheimer JH, De Castro I, McDonnell DE. Minimally invasive spine technology and minimally invasive spine surgery: a historical review. Neurosurg Focus. 2009;27(3):E9.

2. Kazemi N, Crew LK, Tredway TL. The future of spine surgery: New horizons in the treatment of spinal disorders. Surgl Neurol Int. 2013:4(Suppl 1):15-21.

3. Kambin P, Gellmann H. Percutaneous lateral discectomy of the lumbar spine: a preliminary report. Clin Orthop Relat Res. 1983;174:127-32.

4. Mirkovic SR, Schwartz DG, Glazier KD. Anatomic considerations in lumbar posterolateral percutaneous procedures. Spine (Phila Pa 1976). 1995;20(18):1965-71.

5. Cohen MS, Wall EJ, Brown RA, Rydevik B, Garfin SR. AcroMed Award in basic science. Cauda equina anatomy. II: Extrathecal nerve roots and dorsal root ganglia. Spine (Phila PA 1976). 1990:15(12):1248-51

6. Shen J, Wang HY, Chen JY, Liang BL. Morphologic analysis of normal human lumbar dorsal root ganglion by 3D MR imaging. AJNR Am J Neuroradiol. 2006;27(10):2098-103.2.

7. Takashima H, Takebayashi $T$, Shishido $H$, Yoshimoto $M$, Imamura R, Akatsuka $Y$, et al. Comparison with Magnetic Resonance Three-Dimensional Sequence for Lumbar Nerve Root with Intervertebral Foramen. Asian Spine J. 2016;10(1):59-64.

8. Ahn Y, Lee SH, Park WM, Lee HY, Shin SW, Kang HY. Percutaneous endoscopic lumbar discectomy for recurrent disc herniation: surgical technique, outcome, and prognostic factors of 43 consecutive cases. Spine (Phila Pa 1976). 2004;29(16):E326-32.

9. Ruetten S, Komp M. Merk H, Godolias G. Full endoscopic interlaminar and transforamina lumbar discectomy versus conventional microsurgical technique: a prospective, randomized, controlled study. Spine (Phila Pa 1976). 2008;33(9):931-9.

10. Ahn Y, Lee SH, Lee JH, Kim JU, Liu WC. Transforaminal percutaneous endoscopic lumbar discectomy for upper lumbar disc herniation: clinical outcome, prognostic factors, and technical consideration. Acta Neurochir (Wien). 2009:151(3):199-206

11. Yeung AT, Tsou PM. Posterolateral endoscopic excision for lumbar disc herniation: Surgica technique, outcome, and complications in 307 consecutive cases. Spine (Phila Pa 1976). 2002;27(7):722-31

12. Ahn Y, Lee SH, Park WM, Lee HY, Shin SW, Kang HY. Percutaneous endoscopic lumbar discectomy for recurrent disc herniation: surgical technique, outcome, and prognostic factors of 43 consecutive cases. Spine (Phila Pa 1976). 2004;29(16):E326-32.

13. Sairyo K, Matsuura T, Higashino K, Sakai T, Takata Y, Goda Y, et al. Surgery related complications in percutaneous endoscopic lumbar discectomy under local anesthesia. J Med Invest. 2014;61(3-4):264-9.

14. Sakane M. Anatomical relationship between Kambin's triangle and exiting nerve root. Mini-invasive Surg. 2017;1:99-102.

15. Ozer AF, Suzer T, Falsafi M, Aydin M, Sasani M, Oktennoglu T. Anatomic assessment of variations in Kambin's triangle: a surgical and cadaveric study. World Neurosurg. 2017; 100:498-503.

16. Choi PS, Basile R. Estudo anatômico da zona triangular de segurança aplicada aos procedimentos percutâneos póstero laterais. Coluna/Columna. 2003:2(1):19.

17. Vialle $E$, Vialle LR, Contreras W, Jacob Junior C. Estudo anatômico da relação do gânglio da raiz dorsal com o disco intervertebral da coluna lombar. Rev Bras Ortop. 2015;50(4):450-4.

18. Hoshide R, Feldman E, Taylor W. Cadaveric analysis of the Kambin's triangle. Cureus. $2016 ; 8(2): e 475$

19. Hardenbrook M, Lombardo S, Wilson MC, Telfeian A. The anatomical rationale for transforaminal endoscopic interbody fusion: a cadaveric analysis. Neurosurg Focus. 2016;40(2):E12.

20. Lertudomphonwanit T, Keorochana G, Kraiwattanapong C, Chanplakorn P, Leelapattana P, Wajanavisit W. Anatomic Considerations of Intervertebral Disc Perspective in Lumbar Posterolateral Approach via Kambin's Triangle: Cadaveric Study. Asian Spine J. 2016;10(5):821-7.

21. Min JH, Kang SH, Lee JB, Cho TH, Suh JK, Rhyu IJ. Morphometric analysis of the working zone for endoscopic lumbar discectomy. J Spinal Disord Tech. 2005:18(2):132-5.

22. Chhabra A, Zhao L, Carrino JA, Trueblood E, Koceski S, Shteriev F, et al. MR neurography: advances. Radiol Res Pract. 2013;809568.

23. Chhabra A, Lee PP, Bizzell C, Soldatos T. 3 Tesla MR neurography - technique, interpretation, and pitfalls. Skeletal Radiol. 2011:40(10):1249-60.

24. Quester R, Schroder R. The shrinkage of the human brain stem during formalin fixation and embedding in paraffin. J Neurosci Methods. 1997;75(1):81-9.

25. Guan X, Gu X, Zhang L, Wu X, Zhang H, He S, et al. Morphometric analysis of the working zone for posterolateral endoscopic lumbar discectomy based on magnetic resonance neurography. J Spinal Disord Tech. 2015;28(2):E78-84. 